\title{
How Greek Students Experienced Online Education during Covid-19 Pandemic in Order to Adjust to a Post-Lockdown Period
}

\author{
Angelos Giannoulas, Aglaia Stampoltzis, Kalliopi Kounenou and Antonios Kalamatianos \\ School of Pedagogical and Technological Education (ASPETE), Athens, Greece \\ agian@aspete.gr \\ astampoltzi@aspete.gr \\ kkounen@aspete.gr \\ akalamatianos@aspete.gr
}

\begin{abstract}
Following an unprecedented situation of confinement due to the Covid-19 pandemic, academic institutions were called to focus on supporting telecommunications technologies. For the first time, Higher Education went completely online. The authors of this research conducted an online voluntary survey where Greek students could answer questions about the distance education, they had experienced during the Covid-19 lockdown, particularly of the synchronous type. The purpose of this research was to investigate the major issues that created impediments to the students, both the technical barriers that made it difficult to communicate, and the teaching/learning challenges raised because of emerging trends. Recognizing the main problems that arose in the educational process during the lockdown period leads to a better communication in the future in the field of distance education. The students were informed about the research by the Student Counseling Center of their universities but also via posts on well-known student content websites. The research results have shown that most students attended synchronous communication online classes (the theoretical and the practical ones) in replacement of their face-to-face lessons. The students pointed out some negative aspects of online education concerning synchronous communication educational practices, but also how their classes were organized and presented. They referred to the main technical difficulties that occurred - on the part of the teacher - preventing a satisfactory communication, as to the practices that stressed them or to the lack of communication between students and teachers they experienced during the lockdown. Nevertheless, despite these problems, most students are interested in continuing online learning in combination with traditional courses in a classroom. Overall, this study provided important, additional information in respect of the students' perceptions towards online education during the first quarantine.
\end{abstract}

Keywords: Covid-19, Pandemic, Higher education, Distance education, Pedagogy, Attitudes

\section{Introduction}

Mankind is experiencing an unprecedented situation due to the rapid spread of a particularly threatening virus, characterized by uncertainty about the future. With no previous experience, all sectors of society were called upon to face this new ordeal by coping in the best possible way. Without exception, the academic sector had to immediately adapt to this new situation and to continue its work (Schleicher, 2020; Weeden and Cornwell, 2020).

In most countries, education rapidly went online (UNESCO, 2020a; Weeden and Cornwell, 2020), and the Greek educational system was abruptly confronted to online education - while many teachers did not possess any or sufficient skills to keep up with it. This rush was due, on the one hand, to the uncertainty of how the pandemic would develop and, on the other, in order not to raise the issue of having to retake an entire academic year (IESALC, 2020; Ministry of Education in Greece, 2020a).

As in Higher Education, students and teachers also were kept away from campus to continue the educational process via online education. What does this mean for both parts? It means that for a smooth achievement of this new educational process students should adapt to the new modes of delivery while teachers ought to ensure the learning process.

Studies conducted around the world during the lockdown period found that there is a significant percentage of students who felt negatively affected (Means and Neisler, 2020; Quacquarelli Symonds, 2020) and this not only in relation to their academic, but also to their social activities (Killan, 2020). Findings in other studies show in within-person comparisons that students were slightly more anxious and more stressed, on average more depressed and felt lonelier than half a year earlier (Cao et al, 2020; Elmer, et al., 2020; Sundarasen, et al., 2020). 
In view of the aforementioned pandemic crisis' consequences, we investigated the students' experiences and opinions regarding online education, based on various empirical data. According to a survey administered to a national sample of undergraduate students, by Means and Neisler (2020), notwithstanding the large decrease in the students' satisfaction with their online courses, the majority demonstrated satisfaction to a certain degree with the remote instruction. Factors such as the number of challenges and frequency of technology problems were associated with online course satisfaction. Many students cited the difficulty staying motivated to do well in the course as a problem. In addition, Quacquarelli Symonds (2020) pointed out that the proportion of students who are not interested in online degrees has decreased from March to August of 2020. Students' satisfaction regarding online education and factors that affect it, such as website services, platform value, course content, methods of teaching, quality of delivery, learning environment, and tutorials, have been studied in several studies worldwide (Raza, et al., 2020). Finally, dimensions that impact the feasibility and the quality of the online education provided may include technical infrastructure, accessibility, and distance learning competences (Marinoni, et al., 2020). Hence, in order to understand 'how' students experienced these new forms of academic education during the lockdown period in our country, we conducted an online survey, in which undergraduate students were asked to voluntarily answer questions about the problems and challenges they had met.

Our research had a twofold character: to highlight not only the positive and negative points that emerged but also the attitude of students towards online learning, most of them having to admit that it was something quite new.

\section{From the mode of face-to-face teaching to emergency distance learning}

On April $10^{\text {th }}$ of 2020,194 countries decided to close all schools and academic institutions, leaving out some 1.58 billion learners (90.1\% of all learners worldwide) of any formal learning process (UNESCO, 2020b). In order to continue its task, the global academic community had made a rapid transition from formal mode face-to-face to online learning.

In the case of higher education institutions in order to ensure the delivery of courses, online teaching meant using special web communication tools, the so-called synchronous distance education platforms which would work in conjunction with asynchronous communication platforms (course management systems - CMS or learning managements systems - LMS). Countless students were forced to adapt to a completely different way of communicating with their teachers and fellow students, and countless teachers were called upon to adapt to these communication tools and at the same time turn their lesson completely into an online one. Yet despite ensuring the continuation of face-to-face classes with online courses, no one could say the same about equal access for all users, not even about the effectiveness of learning from the educational practices adopted by teachers during the distance learning period.

As in most countries over the world, all academic institutions in Greece had to close after the $10^{\text {th }}$ of March. On the $17^{\text {th }}$ of March the Greek Ministry of Education ordered that in only one week (until the $24^{\text {th }}$ of the same month) the university institutions of the country had to be ready for a complete transition from traditional faceto-face learning to online education (Ministry of Education in Greece, 2020a).

All university institutions were compelled to react immediately to the new requirements. Academic institutions had to show rapid reflexes and seemed to adapt to the processes of synchronous distance education (Raikou, et al., 2020). Students and teachers managed to continue the educational process, the main result of these efforts being the successful completion of the academic semester (Ministry of Education in Greece, 2020b).

Reference is made to modern communication since the staff of all Greek academic institutions in the country has for many years at its disposal asynchronous communication platforms and knows how to use them in combination with face-to-face learning (LMS such as Moodle and e-class, a free open-source asynchronous education platform being the most widespread in Greek academic institutions).

Despite the Greek academic members' experience in asynchronous education, it is natural to have many questions and objections about the feasibility of substituting teaching in the classroom with synchronous online teaching, since online classes have displayed limitations, including time flexibility, problems with internet access and internet connection quality, and insufficient digital skills (Bączek, et al., 2020). Some questions involve the teachers' willingness to use the new tools and adapt their teaching strategies, students' ability to cope with new 
communication forms, plus the availability of an appropriate equipment, and finally, the impact that this whole new situation had on individuals' behavior during the lockdown.

\section{Research design and methods}

In order to be able to better understand and assess the new education conditions related to the transition from classroom to online learning, we created in Google forms an anonymous online survey addressed to undergraduate students of Greek universities. Students could voluntarily respond about both the opportunities and the difficulties of online education during the lockdown.

The research was conducted in collaboration with the Student Counseling Center of School of Pedagogical and Technological Education (ASPETE), through which the respective Counseling Centers of the remaining academic institutions of the country were notified. In order to inform the students, in many institutions a question form was posted on the respective websites of the Counseling Centers as on well-known student content websites.

While the academic institutions closed on March 11, the research website had been collecting answers from May 16 to June 18, just three weeks after the partial reopening of the academic institutions on May 25 (Ministry of Education in Greece, 2020b).

\subsection{Instruments}

The questionnaire include demographic questions about gender, school and year of study, as well as questions of two main categories:

- Category 1: Problems that occurred during online education due to technology and communication tools used (computer/laptop, tablet, mobile phone, microphone, web camera and network connection), and

- Category 2: The educational process and pedagogical challenges during online education.

All questions were closed-ended (see figure and table captions in the 'Findings and discussion' section), giving the possibility of a different answer (Other). Only the last two questions were open-ended:

1. 'What changes should be made in the field of online education in order to help you complete your studies successfully?'

2. 'Do you wish to continue online classes after the lockdown period, and for what reason'

\section{Findings and discussion}

A total of 370 students from 25 academic institutions participated voluntarily, all at undergraduate level (see Figure 1) of which 235 were women (63.5\%) and 135 were men (36.5\%).

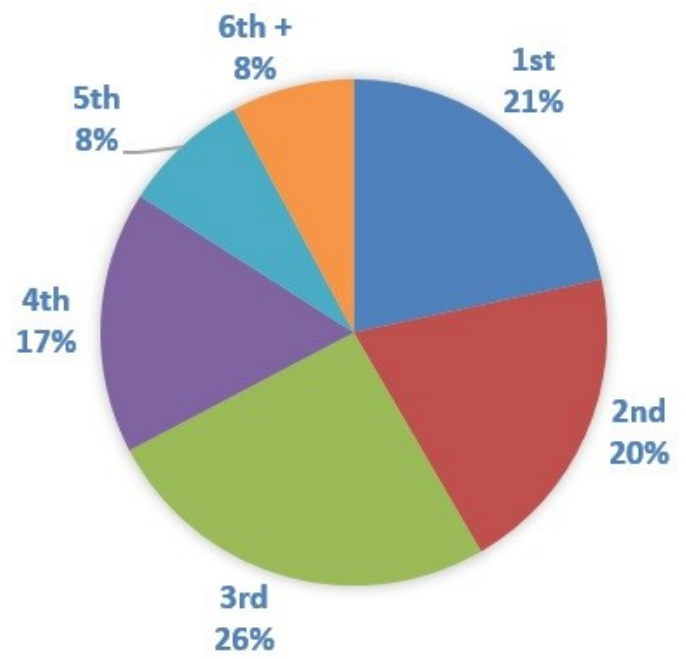

Figure 1: Academic year of undergraduate students who took part in the research

Out of 370 registered students, 341 (92.2\%) answered positively the question whether they agreed to continue or not, a number representing the whole sample of the study. 
First category of questions: Information and Communications technology (I.C.T.) tools used and problems that appeared during distance education.

The students had to say which I.C.T. tools they had been using during online education. $98.2 \%$ had an internet connection in their place of residence during the quarantine period, $53 \%$ of which said that they were satisfied with their connection speed ( $42 \%$ good and $11 \%$ very good). Also, $96.8 \%$ were owners of a personal computer and / or a laptop with $57.6 \%$ of them stating that they do not share it with another person.

In particular, (see Table 1), a high percentage of students stated that they had been using a laptop for their online classes (73\%) and another significant percentage had been using their mobile phone (41.9\%). A certain percentage of students of $26.1 \%$ used a personal computer, while some used a tablet (6.2\%).

Table 1: Computer / Mobile tools used by students during online classes

\begin{tabular}{|l|c|c|}
\hline PC Tool & Total N & Percentage\% \\
\hline Personal Computer & 89 & 26.1 \\
\hline Laptop & 249 & 73 \\
\hline Tablet & 21 & 6.2 \\
\hline Mobile Phone & 143 & 41.9 \\
\hline
\end{tabular}

At the end of this category students were asked to name the technical obstacles they encountered during synchronous communication with their teachers (see Table 2). As it can be seen from the table below, the most common problems were network and interconnection issues (51.3\%), followed by insufficient acoustics which in total reaches $52.8 \%$ namely $14,9 \%$ inability of voice communication on the part of the student and $37.9 \%$ poor acoustics on the part of the teacher. Regarding the weakness or the quality of the image transmission, the percentage amounts to $38 \%$, with $9.6 \%$ for the student's inability to communicate through the image and $28.4 \%$ by the student poor image quality on the part of the teacher. Finally $22.1 \%$ stated that they faced no technical problems.

Table 2: Technical problems you faced during synchronous online classes

\begin{tabular}{|l|c|c|}
\hline Technical problems & Total N & Percentage\% \\
\hline Frequent connection problems & 172 & 51.3 \\
\hline Inability of voice communication on the part of the student & 50 & 14.9 \\
\hline Poor acoustics & 127 & 37.9 \\
\hline Inability of the student to communicate on screen & 32 & 9.6 \\
\hline Poor image & 95 & 28.4 \\
\hline I had no problem & 74 & 22.1 \\
\hline
\end{tabular}

Indicative answers given in the field "Other" are also mentioned, which we consider to be important for understanding communication problems, such as:

- $\quad$ Poor infrastructure for lessons that required exercise solving (lighting, cameras with 240p-480p resolutions) if 720 is not HD I think it is a very big drawback as we cannot keep clear notes"

- " "If too many people were online, we were being thrown out of the system"

- $\quad$ "My eyes got tired whenever I had to watch the lesson due to the small screen of my mobile phone. Plus, the teachers did not post the material of the next lesson in the e-class so that we could have accessed the lesson from there and listen to them on our mobile phone"

- $\quad$ "I would run out of Megabytes".

Second category of questions: The educational process and pedagogical challenges during online education

First of all, the students were asked about how often they had attended synchronous online theoretical and practical (laboratory) courses (if the schedule planned any). As for the theoretical courses, the answers "Very often" to "Always" were given by $72.4 \%$ of the students, while $14.1 \%$ answered that they had been attending those classes at a "moderate frequency".

Of all the students, $71.6 \%$ also had to attend practical (laboratory) courses, $89.5 \%$ attending from "Very often" to "Always" and 5.1\% at a "moderate frequency". 
The questions that followed reveal the students' attitude towards synchronous online education, as they were experiencing it for the first time. So, we asked them to rate the whole process from 1 (I do not like it at all) to 5 (I like it very much) (see Figure 2). Most students rated it as an average of 3 (35.2\%), while $41.6 \%$ chose the most positive rates, from $4(26.9 \%)$ to $5(14.7 \%)$. On the contrary, $23.2 \%$ consider distance education to be below average (7.9\% for 1 and $15.3 \%$ for 2$)$.

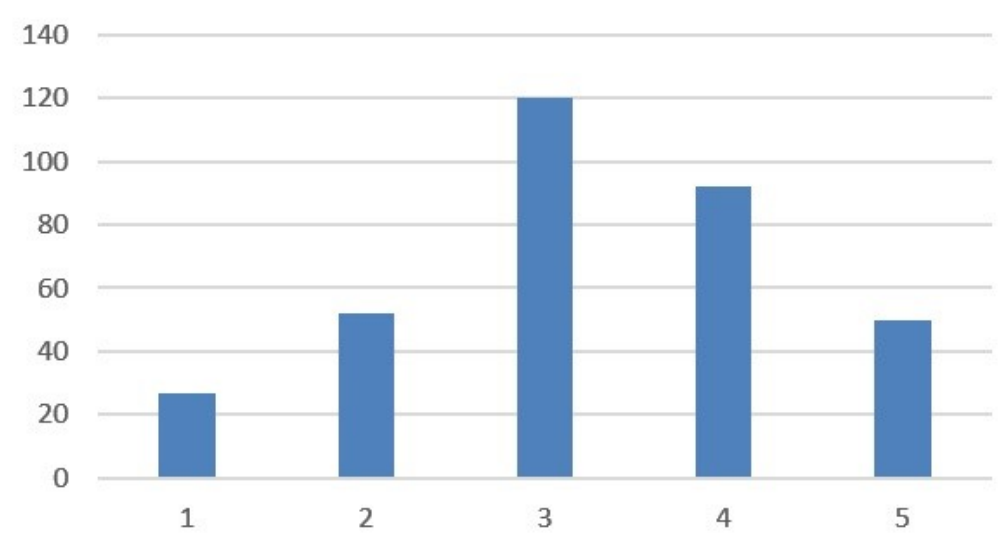

Figure 2: From $1=$ I do not like at all up to $5=$ I like it very much, how do you evaluate your experience so far with your online classes?

Students were then asked to report cases where distance learning communication methods create negative emotions (see Table 3). In the case of synchronous communication, the negative emotions were provoked by "Tiring and long lectures" (47.5\%), the "Lack of interaction" (39.6\%), the "Sense of lack of communication with the teacher" (35.5\%) and finally "An exclusive use of slides" (33.7\%). In the case of asynchronous communication, the option "Lack of feedback" (15.8\%) appears at a smaller percentage as well as the "Poor class material organization" (15.2\%). Finally, 13.5\% had nothing negative to report.

Table 3: When online classes create negative emotions

\begin{tabular}{|l|c|c|}
\hline Negative emotions & Total N & Percentage\% \\
\hline Lack of communication with the teacher & 121 & 35.5 \\
\hline Frequent use of slides & 115 & 33.7 \\
\hline Lack of interaction & 135 & 39.6 \\
\hline Boring and long lectures & 162 & 47.5 \\
\hline Lack of feedback & 54 & 28.4 \\
\hline Poor class material organization & 52 & 15.2 \\
\hline Nothing negative to report & 46 & 13.5 \\
\hline
\end{tabular}

Being asked what stressed them while having online classes during the quarantine period (see Table 4), most of students referred to "Having to spend hours in front of a computer screen" (73\%). "Fatigue / inability to concentrate" comes second in options (46.9\%) and then "Feeling lonely or isolated" (30.8\%).

A percentage of $12.9 \%$ also referred to issues of "Disruption to family life" while $16.4 \%$ of them reported no impact.

Table 4: What stressed students during online education

\begin{tabular}{|l|c|c|}
\hline Triggering fact & Total N & Percentage\% \\
\hline Long hours in front of a screen & 249 & 73 \\
\hline Feeling of fatigue or inability to concentrate & 160 & 46.9 \\
\hline Feeling of loneliness or isolation & 105 & 30.8 \\
\hline None & 56 & 16.4 \\
\hline Disruption to family life & 44 & 12.9 \\
\hline
\end{tabular}

To the question "What do you miss most during your online learning period?" (see Figure 3), the students indicated as their first choice the "Face-to-face and interactive contact communication with their fellow 
students" (74.5\%), the "Possibility of direct communication with the teacher" as the second (57.5\%) and last, with a percentage of $51 \%$, their "Physical presence in class".

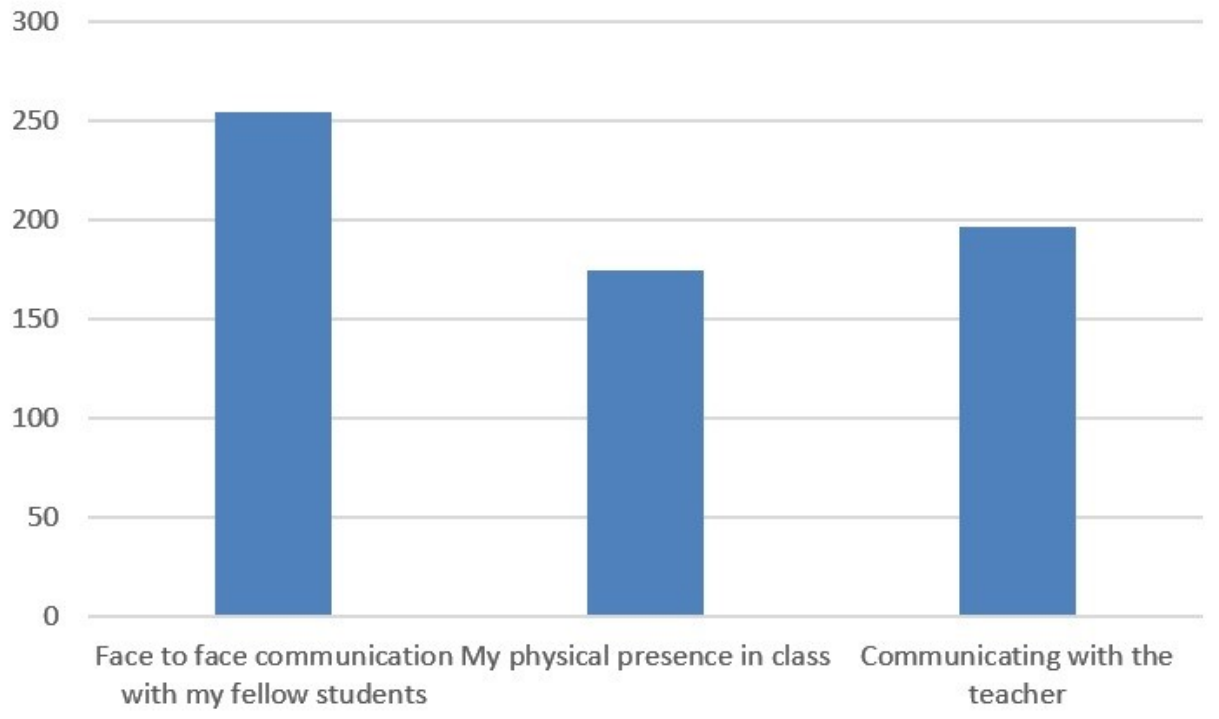

Figure 3: What do you miss most during your online learning period?

In the next question we asked the students to give us their opinion about what changes should be made in the field of online education so that they can successfully complete their studies. The question was open-ended and we received a total of 166 answers. In order to be able to understand the students' answers, we created 6 categories of content (see Figure 4).

First category of answers: Technical issues (3\%)

The students proposed that a higher speed and broadband connections stability or the combinatorial use of special online applications with the synchronous distance education platform would improve the communication process.

Second category of answers: Back to the classroom (8.4\%)

The percentage of students, as shown above, prefer to attend conventional classes and take part in face-to-face lessons.

Third category of answers: Organization (32.5\%)

This category is about a better organization of the teaching material and any form of material shared through the asynchronous education platforms (for instance e-class or Moodle), an immediate feedback from the teacher regarding any kind of change, a better preparation of the lesson by the teacher during synchronous communication, but also the knowledge of the use of electronic tools by the teacher to achieve a better communication.

Typical is the response of a student: "All I would say is that maybe some people should be more organized, (teachers did not always send email with the link permitting us to participate in the course, they just forgot) but I understand that they are quite lost because there are so many new things to handle"

Fourth category of answers: Educational practices (56.6\%)

The largest percentage of answers was about issues related to the educational practices used by their teachers during synchronous communication. References are made to the lack of interaction and communication, to the long lectures, insufficient breaks, to the insufficiency of choices of different means and ways of transmitting information during class. 
Here are some of the students' requests as follows:

- $\quad$ "A better interaction with teachers. Students should not be mere receptors of information-without being able to participate"

- "The pdf-files in the e-class without further explanation and discussion have no meaning for me. It takes me many hours to understand them and at some point I just give up" (e-class is a LMS)

- "More interaction and not just a bunch of dry lectures"

- $\quad$ "... teachers should be more interested in the quality of the lesson than in the quantity of the material... they should be willing to change the way they teach"

- $\quad$ "Teachers should try as much as possible to address the students for a discussion and use other means to transmit knowledge, for instance through movies, articles"

- $\quad$ "i'm really terribly bored and having to sit all day in a chair is just freaking me out"

Fifth category of answers: Inclusive education (3.6\%)

This percentage of responses ranged from issues like the concern on the part of the teacher, the Faculty and the Greek State. They refer to the insufficient assistance to students with learning difficulties, and to the lack of a minimum necessary electronic material to achieve online communication. The following answers are indicative:

- $\quad$ Providing care and counseling on how a student with learning difficulties should deal with distance learning"

- “... help students who do not have access to a computer or to the internet... "

Sixth category of answers: I do not want any change - No changes $(6.6 \%)$

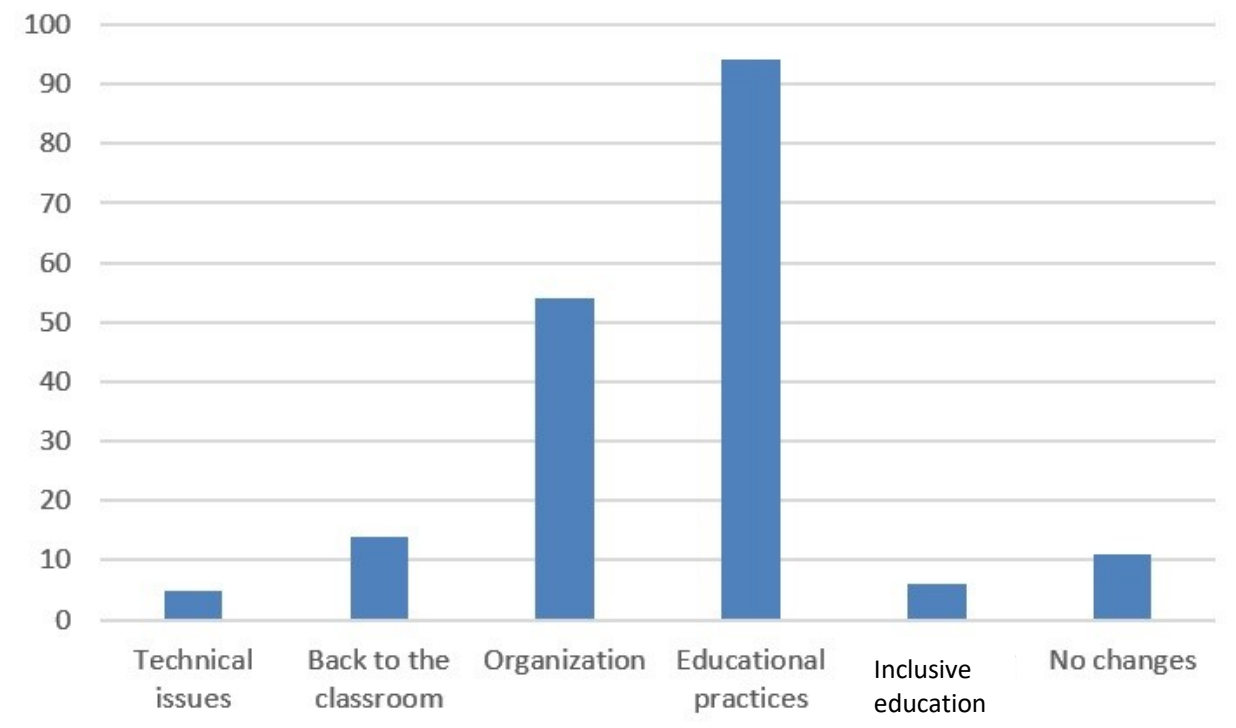

Figure 4: What changes should be made in the field of online education in order to help you complete your studies successfully?

Finally, the students were asked if they wished to continue online classes after the lockdown period, and for what reason. There were 197 positive answers (57.8\%) and 166 of the students justified their opinion.

Because the question was open-ended, according to the answers we received, we proceeded to classify them into 3 main categories (see Figure 5).

First category of answers: Special conditions (33.1\%)

Here we included answers that contained a particular or personal condition, such as the existence of financial problems, plus issues concerning members of vulnerable groups or people with family issues. Indicatively, we are quoting the following answers:

- "This was a fortunate situation for me, because I am mother of a baby and I have nobody to help me. This was the only way for me to attend classes"

- "I am member of a vulnerable group. For this reason, online classes helped me avoid being exposed"

- "Online lessons helped me because I may not be able to afford to attend lessons (rent, travel expenses)" 
Second category of answers: A different educational practice (14.5\%)

This category includes answers relating to the educational practices students experienced during the lockdown. Indicative information:

- $\quad$ "In the current situation, some teachers send us earlier the material that they would teach in their lesson, so that we have an idea of what we will discuss in class. This is very useful, because I have already studied the material and I can ask questions (when this does not happen and we are being sent the material later, eventual questions are being rejected because they tell us that they have already explained them in previous lessons)"

- $\quad$ "It helped me a lot because I could watch the videos that the teacher had sent whenever I wanted and as many times I wanted in order to understand the lesson"

Third category of answers: Time saving (59.6\%)

Some students thought that it would be important to continue online education because it helped them save time, especially for those who have to cover long distances in order to get to class. The following answers are indicative:

- $\quad$ "I cover long distances to get to my Faculty, spending money on food and drinks all day since I do not have the opportunity to return home and leave again. Usually if the next lesson is late, I decide not to attend it."

- "Because I need two and a half hours to go to the university and back"

- "I belong to those students who need to work while studying. Therefore, distance learning helps me to have more free time that can be used for studying".

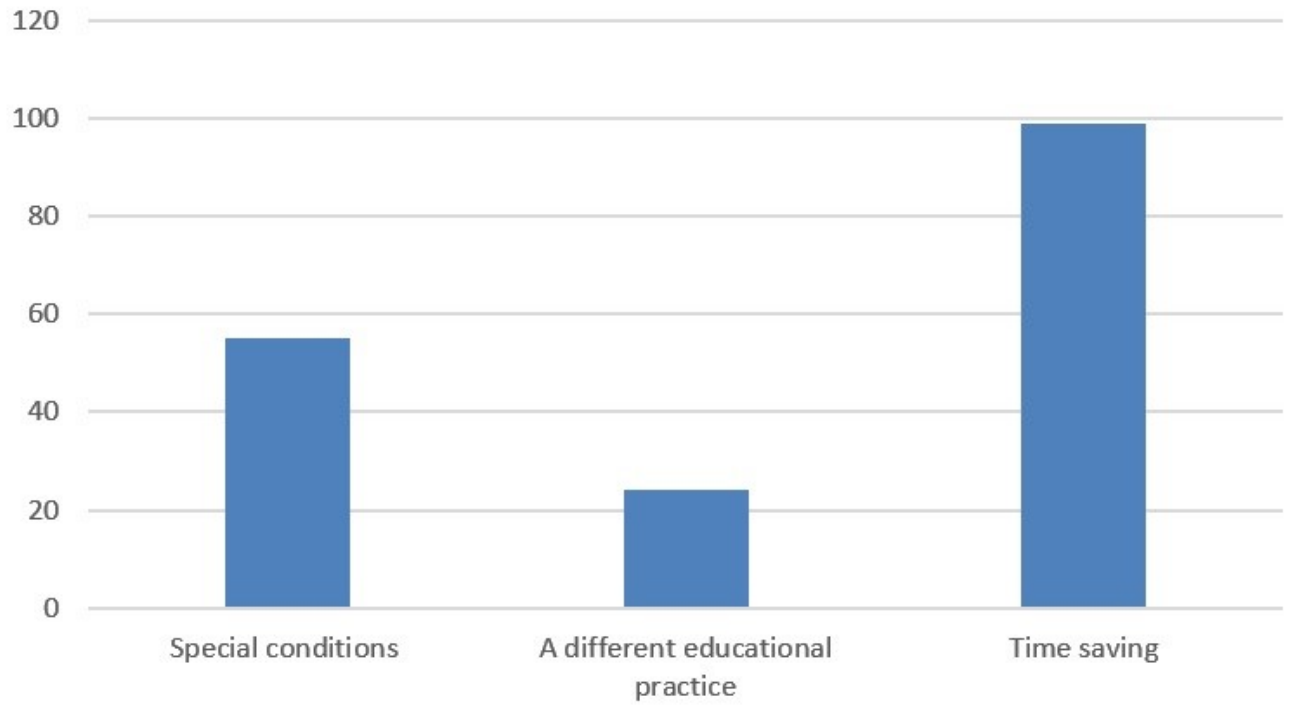

Figure 5: Why do you want to continue online learning?

\section{Discussion}

The aim of the present nationwide study, that took place during the first quarantine period, was to identify the major issues that created impediments to the students, with respect to their learning process of online education, and their attitudes towards it, and to explore the changes that could be implemented so as to improve the online academic services provided.

It is positive to see that almost all of the students were able to have access to the internet in their place of residence during the lockdown (98.2\%), as well as access to a Personal Computer or to a laptop (99.1\%) (Table 1).

Moreover, it is encouraging for the whole effort of the academic community to see that the attendance frequency of online lessons ranges from "Very often" to "Continuously" (72.4\%). Especially in the case of online practical courses (laboratory) the attendance rate reached $89.5 \%$. It should be emphasized that the difference may be due to the mandatory attendance that many Departments specify for their laboratory courses. 
We should mention the high percentage of students that used the mobile phone for their online lessons ( $41.9 \%$, Table 1). It has been proven that the educational use of mobile phones in combination with classroom education, contributes positively to teaching and learning processes (Mileva, 2011; Draves, 2013, p.257). However, we cannot conclude that it has a positive contribution in the case of absolute online learning, such as in the delivery of exercises or practical courses, or even in the reading and studing of digital material, because in that case different designs are needed for mobile devices (Ozdamli and Cavus, 2011).

Certainly, many problems regarding oral or visual communication can be easily be solved, either with the help of people with know-how or by replacing some communication tools (for example camera, microphone, etc.). The fact that a large percentage of students answered that they did not have a reliable connection during their online education (51.3\%, Table 2 ) can only be disquieting, not only in terms of the online courses they underwent during the lockdown but mainly in the event of a similar situation during the new academic year.

The majority of them report that what they missed the most was the communication with their fellow students (74.5\%, Figure 3), but also with the teachers (57.5\%). Research has shown that the quality of conversations is reduced through technology and mobile communication devices, although the frequency of communication is higher (Przybylski and Weinstein, 2012; Misra et al, 2014; Drago, 2015). It is notable that 30.8\% of the students that took part in this survey stated that this was one of the reasons that made them feel lonelier or more isolated (Table 4). Similarly, Karalis and Raikou (2020) noted that most students consider online, in comparison with faceto-face education, as lacking collaboration, social interaction, and socialization.

Furthermore, $47.5 \%$ of the students evaluated negatively the long lectures during online lessons (Table 3). Even if the combination of course material - students - teacher interactions has been proved as one of the most important reasons in a successful online course (Swan, 2003), in our case $39.6 \%$ said to have been missing the interaction and participation between students as well as between students and the teacher that existed during courses former to the lockdown.

Additional negative aspects that the students pointed out are the frequent use of slides in the lessons (33.7\%), an insufficient organization of the learning material (15.2\%) and the lack of feedback (28.4\%) (Table 3). We could mention in a few words to the organization of the courses, aspects which are also pointed out by the answers given to the question "What would you like to change about the education you are benefitting from?" Specifically, in the category "Organization", they referred to the need to change the structure and presentation of the material, but also to issues related to how teachers prepare their lesson (32.5\%, Figure 4). It would be more helpful if the course material was segmented and presented in modules (Clark and Mayer, 2011, p.39; Draves, 2013, p.13, 66).

The above results in combination with the technical problems mentioned in the students' answers (see Table 2), underline the need for a better knowledge of communication applications both in the synchronous and in the asynchronous form.

Schleicher (2020, p. 16) refers to the lack of training of a significant percentage of teachers in ICT distance education. This lack is likely to affect the teaching practices that teachers choose in their communication but also in the way they create, share and present their educational material.

In addition, 3.6\% referred to the need to enhance learning opportunities by helping categories of students that are in need, either because they face either learning difficulties or financial issues (Figure 4).

The previous results help us better understand the attitude of students towards online education, that $41,2 \%$ of them evaluated as "Good" or "Very Good" (see Figure 2) whereas the rest of the students rated it up to "Average".

Finally, we should not overlook the students' answers on why they want to continue their studies partly online in the post-pandemic era (Figure 5). It is impressive that more than half of them answered positively to that question (57.8\%). The majority refers to reasons like saving time (mainly referring to the time needed to get to their Faculty and back), but also to personal conditions (health, financial reasons, social obligations, etc.) at a rate of $33.1 \%$. This conclusion is in accordance with Karalis and Raikou (2020) who also observed that students 
were in favor of online teaching, because participation in the class was easier, and the difference compared to the usual process was exciting. Moreover, Baczek, et al. (2020) noted that medical students considered elearning as an effective in increasing knowledge and valuable teaching method.

\section{Conclusion}

This research focuses on the views of undergraduate students regarding online education during the lockdown. It is a fact that previously to the lockdown due to Covid-19, online education had not been, for most students and teachers, adopted as the formal teaching and learning methodology and that this mode of education is clearly different from face-to-face lessons in a classroom.

Looking ahead to the new academic year and with many restrictions still in place, the academic world is very well aware that it should be prepared as appropriately as possible. Certainly, online learning has come to stay. It is most certain that the use of online communication can help a wider range of students have access to education. However this does not mean that it will exclusively be the only form of education to the detriment of a traditional face-to-face one. Likewise, in the study of Raikou, et al. (2020) with students at two Greek universities evaluated positively the online education on account of the development of new skills, the convenience of attending courses in their own environment, time and pace, and the improvement of ICT skills.

Whatever measures are taken, a percentage of education will still be online, meaning that in the first postlockdown era the academic community ought to take care of any issues, deficiencies and inequalities that may have arisen during the lockdown period.

\section{Acknowledgements}

We would like to express special thanks to the students who participated in the research as well as to the Counseling Center of the Higher School of Pedagogical and Technological Education (ASPETE) along with the other Counseling Centers of the other Greek academic institutions that contributed to this research by notifying it to their students via their webpages.

The authors acknowledge financial support for the dissemination of this work from the Special Account for Research of ASPETE through the funding program "Strengthening ASPETE's research".

\section{References}

Bączek, M., Zagańczyk-Bączek, M., Szpringer, M., Jaroszyński, A. and Wożakowska-Kapłon, B., 2020. Students' perception of online learning during the Covid-19 pandemic: a survey study of Polish medical students. Research Square, 1-14.

Cao, W., Fang, Z., Hou, G., Han, M., Xu, X., Dong, J. and Zheng, J., 2020. The psychological impact of the Covid -19 epidemic on college students in China. Psychiatry Research, 287: 12934.

Clark, R. C., and Mayer, R. E., 2011. E-learning and the science of instruction: proven guidelines for consumers and designers of multimedia learning. San Francisco: Pfeiffer.

Drago, E., 2015. The effect of technology on face-to-face communication. The Elon Journal of Undergraduate Research in Communications, 6(1), pp.13-19.

Draves, W., 2013. Advanced teaching online. River Falls: Learning Resources Network.

Elmer, T., Mepham, K. and Stadtfeld, C., 2020. Students under lockdown: comparisons of students' social networks and mental health before and during the Covid -19 crisis in Switzerland. PLOS ONE, 15(7), p.e0236337.

IESALC, 2020. Covid -19 and higher education: today and tomorrow: impact analysis, policy responses and recommendations. [ebook] Available at: <http://www.iesalc.unesco.org/en/wp-content/uploads/2020/04/COVID-19EN-090420-2.pdf> [Accessed 2 November 2020].

Karalis, T. and Raikou, N., 2020. Teaching at the times of Covid -19: inferences and implications for higher education pedagogy. International Journal of Academic Research in Business and Social Sciences, 10(5), 479-493.

Killian, J., 2020. College students, professors adjust to Covid -19 life. [online] NC Policy Watch. Available at: <http://www.ncpolicywatch.com/2020/04/01/college-students-professors-adjust-to-covid-19-life/> [Accessed 30 August 2020].

Marinoni, G., van't Land, H. and Jensen, T., 2020. The impact of Covid-19 on higher education around the world: IAU global survey report. [ebook] Paris: International Association of Universities. Available at: <https://www.iauaiu.net/IMG/pdf/iau_covid19_and_he_survey_report_final_may_2020.pdf> [Accessed 28 January 2021].

Means, B. and Neisler, J., 2020. Suddenly online: a national survey of undergraduates during the Covid-19 pandemic. [online] Digitalpromise.org. Available at: <https://digitalpromise.org/wpcontent/uploads/2020/07/ELE_CoBrand_DP_FINAL_3.pdf> [Accessed 7 September 2020].

Mileva, N., 2011. The effectiveness of mobile learning in the form of performance support system in higher education. International Journal of Interactive Mobile Technologies (iJIM), 5(4), pp.17-21. 
Ministry of Education in Greece, 2020a. Briefing of the deputy Minister of education on distance education in universities. [online] Available at: <https://www.minedu.gov.gr/news/44365-17-03-20-enimerosi-tou-yfypourgoy-paideiasthriskevmaton-gia-tin-eks-apostaseos-ekpaidefsi-sta-aei-2> [Accessed 29 August 2020].

Ministry of Education in Greece, 2020b. Gradual reopening of structures of education. [ebook] Athens. Available at: <https://mathainoumestospiti.gov.gr/wp-content/uploads/2020/04/minedu-covid19-mathainoumestospiti-neametra290420.pdf> [Accessed 29 August 2020].

Misra, S., Cheng, L., Genevie, J. and Yuan, M., 2014. The iPhone effect. Environment and Behavior, 48(2), pp.275-298.

Ozdamli, F. and Cavus, N., 2011. Basic elements and characteristics of mobile learning. Procedia - Social and Behavioral Sciences, 28, pp.937-942.

Przybylski, A. and Weinstein, N., 2012. Can you connect with me now? How the presence of mobile communication technology influences face-to-face conversation quality. Journal of Social and Personal Relationships, 30(3), pp.237246.

Quacquarelli, Symonds, 2020. The Impact of the coronavirus on global higher education: exclusive QS survey data reveals how prospective international students and higher education institutions are responding to this global health emergency. [ebook] Available at: <https://info.qs.com/rs/335-VIN-535/images/The-Impact-of-the-Coronavirus-onGlobal-Higher-Education.pdf> [Accessed 2 September 2020].

Raikou, N., Kaltsidis, C., Kedraka, K. and Karalis, T., 2020. Teaching in times of Covid-19 pandemic in two peripheral Greek universities: lessons learned from students' experiences and opinions. Research Journal of Education, 6(8), 135-143.

Raza, S., Khan, K. and Rafi, S., 2020. Online education \& MOOCs: teacher self-disclosure in online education and a mediating role of social presence. South Asian Journal of Management Sciences, 14(1), pp.142-158.

Schleicher, A., 2020. The impact of Covid-19 on education - insights from education at a glance 2020. [ebook] OECD. Available at: <https://www.oecd.org/education/the-impact-of-covid-19-on-education-insights-education-at-a-glance2020.pdf> [Accessed 27 October 2020].

Sundarasen, S., Chinna, K., Kamaludin, K., Nurunnabi, M., Baloch, G., Khoshaim, H., Hossain, S. and Sukayt, A., 2020. Psychological impact of Covid-19 and lockdown among university students in Malaysia: implications and policy recommendations. International Journal of Environmental Research and Public Health, 17(17), p.6206.

Swan, K., 2003. Learning effectiveness online: what the research tells us. Elements of quality online education. Practice and Direction, 4, pp.13-47.

UNESCO, 2020a. National learning platforms and tools. [online] Available at: $<$ https://en.unesco.org/covid19/educationresponse/nationalresponses> [Accessed 18 September 2020].

UNESCO, 2020b. Education: from disruption to recovery. [online] Available at: $<$ https://en.unesco.org/covid19/educationresponse> [Accessed 2 November 2020].

Weeden, K. and Cornwell, B., 2020. The small-world network of college classes: implications for epidemic spread on a university campus. Sociological Science, 7, pp.222-241. 